\title{
Kilka uwag o książce Oskara Kaneckiego Sądy kapturowe Wielkiego Księstwa Litewskiego (1572-1764), Sopot: Wydawnictwo Arcbe Marek Jokarczyk, 2020, ss. 341
}

\author{
Abstract \\ Some Remarks on Oskar Kanecki's Book Sąy kapturowe Wielkiego Księstwa \\ Litewskiego (1572-1764) [Interregnum courts of law in the Grand Duchy \\ of Lithuania (1572-1764)], Sopot: Wydawnictwo Arche Marek Tokarczyk, \\ 2020, pp. 341
}

Oskar Kanecki's book considerably broadens the state of knowledge of the judiciary of the Grand Duchy of Lithuania during the interregnum periods $\left(16^{\text {th }}-18^{\text {th }}\right.$ century). The work deals with the genesis, organisation and process before these courts in an interesting and wide-ranging way. It seems that a drawback of the book is the incomplete use of the Statute of Lithuania and legislation.

Keywords: courts for nobility, Grand Duchy of Lithuania, interregnum

Słowa kluczowe: sądownictwo szlacheckie, Wielkie Księstwo Litewskie, interregnum

Wyjątkowa, pociągająca specyfika sądów kapturowych mieszczących się w segmencie instytucji właściwych okresom bezkrólewi w przedrozbiorowej Rzeczpospolitej, a zarazem będących pewną formą zawsze atrakcyjnego problemu szlacheckiego wymiaru sprawiedliwości już od bardzo dawna budzi zainteresowanie badaczy polskich i obcych, ale dorobek piśmiennictwa odnoszący się do tego zagadnienia nie jest bardzo obfity. Znaczna jego część, na czele z monografią autorstwa Andrzeja Abramskiego i Andrzeja Hurasa $^{1}$, dotyczy różnych aspektów funkcjonowania tych jurysdykcji w Koronie. Do kapturów litewskich oczywiście nawiązywano, ale czyniono to najczęściej w związku z badaniami nad poszczególnymi sejmikami, sądami czy też doniosłymi wydarzeniami politycznymi doby bezkrólewi, a rzadziej, i jeśli już, to zazwyczaj w drobniejszych for-

1 Abramski, Huras, Sądy. 
mach, bezpośrednio. Monografia Oskara Kaneckiego poświęcona sądom kapturowym w Wielkim Księstwie Litewskim (WKL) znacznie szerzej uchyla drzwi do poznania tego doniosłego problemu.

Książka składa się ze wstępu, pięciu rozdziałów i zakończenia, które uzupełniają wykazy źródeł i opracowań, skrótów oraz spis rycin. Opracowanie nie zawiera obcojęzycznego streszczenia. W pracy przyjęto przedmiotowo-chronologiczny układ materii. Zamiarem autora było ukazanie organizacji i funkcjonowania sądów kapturowych w Wielkim Księstwie Litewskim w XVI-XVIII w., a zasadniczym celem ,„przedstawienie zakresu, w jakim kaptury zastępowały sądy zwyczajne” (s. 19). Autor dążył też do ustalenia, jaki wpływ na działalność sądów kapturowych miały nadzwyczajne warunki, w których znajdowało się państwo w dobie interregnum. O. Kanecki podjął ponadto próbę zidentyfikowania ewentualnych odstępstw od stosowania w tym newralgicznym czasie obowiązującego na Litwie prawa statutowego oraz wyśledzenia wszelkich korekt, jakie zachodziły w stylu funkcjonowania sądów. Takie ujęcie wymagało analizy nie tylko norm ustrojowych i z zakresu prawa procesowego, ale także odsłonięcia fragmentów praktyki oraz odwoływania się do ówcześnie aktualnych uwarunkowań społeczno-politycznych. Szeroki, bo obejmujący ponad dwa stulecia, zakres chronologiczny pracy pozwolił na rzucenie światła na okoliczności i proces narodzin sądów kapturowych po śmierci Zygmunta Augusta, dalej na ich wiek dojrzały, kiedy funkcjonowały już jako w pełni ukształtowane instytucje, a wreszcie na ich schyłek przypadający na wiek XVIII. Autor zauważył, że o ile zasadnicze wzorce i mechanizmy wyrobione w XVI w. były reprodukowane w kolejnych stuleciach, to ich stosowanie w zmienionych przez upadek obyczajów politycznych i obcą ingerencję warunkach, przyniosło sądom kapturowym kryzys i wyraźne oznaki dysfunkcjonalności. Autor zdaje się aprobować wysuwaną w piśmiennictwie opinię, że wyraźną cezurą było tu bezkrólewie po śmierci Jana III Sobieskiego.

O. Kanecki wykorzystał pokaźną ilość materiałów rękopiśmiennych, które umożliwiły wejrzenie w działalność sądów kapturowych na terytoriach wchodzących w skład województwa wileńskiego, trockiego, smoleńskiego, witebskiego, nowogródzkiego, brzeskolitewskiego, mińskiego, połockiego, mścisławskiego oraz Księstwa Żmudzkiego. Wydobył je z zasobów krajowych przechowywanych w: Archiwum Głównym Akt Dawnych w Warszawie, Archiwum Narodowym w Krakowie, Archiwum Państwowym w Łodzi, Bibliotece Książąt Czartoryskich w Krakowie, Bibliotece Narodowej w Warszawie, Bibliotece Naukowej Polskiej Akademii Umiejętności i Polskiej Akademii Nauk w Krakowie, Bibliotece Polskiej Akademii Nauk w Kórniku, Zakładzie Narodowym im. Ossolińskich we Wrocławiu, a także placówkach zagranicznych, a więc: Łotewskim Państwowym Archiwum Historycznym w Rydze, Bibliotece Litewskiej Akademii Nauk im. Wróblewskich w Wilnie, Archiwum Historycznym Państwa Litewskiego w Wilnie, Bibliotece Uniwersytetu Wileńskiego, Narodowym Archiwum Historycznym Białorusi w Mińsku, Narodowej Bibliotece Białorusi w Mińsku, Rosyjskiej Narodowej Bibliotece w Sankt Petersburgu, Petersburskim Instytucie Historii Rosyjskiej Akademii Nauk w Sankt Petersburgu. Autor zdobył także dokumenty sądowe i źródła epistolarne z archiwum podworskiego z Czombrowa k. Nowogródka, pozostającego w zbiorach prywatnych. Rolę rdzenia fundamentu źródłowego pracy odegrały księgi kapturowe wydobyte ze zbiorów wileńskich i mińskich, które dostarczyły znacznego materiału pozwów, relacji z czynności 
procesowych, wyroków, ale i protestacji oraz różnorodnych pism spływających do sądów kapturowych. Wiele wniosły zachowane w Wilnie rejestry spraw. Dla uchwycenia właściwości organizacyjnych sądów doby bezkrólewia oraz stosowanej w ich praktyce procedury pomocne okazały się lauda sejmikowe. Penetracja rozsypanego materiału rękopiśmiennego przyniosła korzyść w postaci instrukcji sejmikowych, pism procesowych, dekretów, diariuszy, uniwersałów oraz korespondencji.

Wśród źródeł drukowanych znalazły się konstytucje sejmowe, ale także akty zjazdów stanów WKL doby bezkrólewia, diariusze sejmów konwokacyjnych, elekcyjnych i koronacyjnych, lauda sejmikowe, uniwersały i wyroki sądów kapturowych, teksty ugód zawartych przez strony, wnioski o dylacje, a także korespondencja oraz różnego charakteru pamiętniki, wspomnienia, dzienniki, diariusze pisane przez przedstawicieli wybitniejszych familii szlacheckich. Solidną bazę źródłową uzupełnia literatura przedmiotu. Wykaz spożytkowanych opracowań zawiera ponad 250 pozycji.

Rozdział Izatytułowany „Kształtowane się sądownictwa doby bezkrólewia”(s. 33-84) autor rozpoczął od refleksji na temat przyczyn zawieszenia funkcjonowania sądów po zgonie monarchy, wskazując, że u podstaw tego zjawiska leżała teoria zastępstwa. Zatrzymał się dalej nad pojęciem sądów kapturowych, a w związku z tym nad wieloznacznością terminu „kaptur”; wymienił konteksty, w których bywał on używany oraz przypomniał poglądy wyrażane w piśmiennictwie w związku z tą kwestią, ale nie przedstawił wyraźnie własnej interpretacji. Lektura wywodów wstępnych automatycznie nasuwa, prawda, niełatwe pytanie, na które na kartach opracowania czytelnik nie znajduje odpowiedzi, a mianowicie o praźródło, o pierwsze początki idei powoływania sądów kapturowych. Zarysował dalej autor proces gruntowania się na Litwie od końca XVI stulecia wzorem Korony zasady ex morte regis iudicia omnia cessant, która znalazła odzwierciedlenie w licznych źródłach (na przykład w enuncjacjach i działaniach deputatów do Trybunału Litewskiego, aktach sejmikowych i innych). W kontekście wspomnianej reguły poruszył także problem pojawiających się ograniczeń w przyjmowaniu wpisów i wybierania widymusów oraz sposobów, które przedsiębrano w celu ich przezwyciężenia. Z obserwacji autora zdaje się wynikać, że główna rola, co niespecjalnie dziwi, przypadła w tej mierze księgom grodzkim. Podniósł dalej problem zaprzestania egzekwowania wyroków, która to praktyka nie znalazła uznania w oczach części szlachty litewskiej, oraz kwestię mocy dekretów (sądów ziemskich, grodzkich, Trybunału), które wydano przed opublikowaniem aktów prymasowskich informujących o zgonie monarchy i rozpoczętym bezkrólewiu. $Z$ przeprowadzonych wywodów wynika, że w tym ostatnim przypadku nie było kontrowersji co do formuły, że wyroki te zachowują swój walor. Nieco miejsca poświęcono omówieniu komplikacji, które dla realizacji zasady ex morte regis iudicia omnia cessant przyniosły burzliwe wydarzenia XVIII w. związane z detronizacją Augusta II, elekcją Stanisława Leszczyńskiego, a znacznie później z dwukrólewiem po śmierci Wettyna (do wątków tych w różnych kontekstach nawiązywał autor w dalszych rozważaniach). Autor przypomniał też poglądy Władysława Sobocińskiego na temat idącego $\mathrm{w}$ parze $\mathrm{z}$ zawieszaniem działalności sądów zniesienia porządku prawnego i zgodził się z historykiem, że „,zarówno ustawanie po zgonie monarchy mocy obowiązującej aktów prawnych, jak i jej przywracanie po koronacji nowego władcy było jedynie fikcją, której hołdowano jednak aż do upadku Rzeczypospolitej" (s. 54). Następnie sporo miejsca poświęcił bliższemu wejrzeniu w proces kształtowania się modelu litew- 
skiego sądownictwa doby bezkrólewia na przełomie XVI i XVII w., a więc kolejno po śmierci Zygmunta Augusta, opuszczeniu kraju przez Henryka Walezego, zgonie Stefana Batorego. Oczywiście po zejściu ostatniego Jagiellona reakcje szlachty po powiatach musiały być zróżnicowane i nie wszędzie powołano jurysdykcje kapturowe. O. Kanecki przypuszcza, że najwcześniej (4 sierpnia 1572 r.), choć dowód jest pośredni, uczyniono to w Brześciu Litewskim, gdzie sprawy kryminalne powierzono lokalnemu sądowi grodzkiemu, do którego składu dodano trzech deputatów obranych na sejmiku. Niemal równolegle miały powstać sądy kapturowe w Pińsku i Lidzie. Autor zwraca uwagę, że ten przejaw odruchu obronnego w newralgicznym czasie mógł być wynikiem inspiracji praktykami koronnymi, a więc obserwowanym po sąsiedzku zawiązywaniem konfederacji i powoływaniem przez nie sądów. W niektórych powiatach na Litwie funkcjonowały jednak dalej w najlepsze w niezmienionym składzie i w tym samym zakresie dotychczasowe sądy grodzkie. Przed przejściem do uwag na temat specyfiki funkcjonowania sądownictwa w zupełnie nadzwyczajnej sytuacji, jaka zaistniała po ucieczce Walezego do Francji (18 czerwca 1574 r.), a potem na temat porządku powoływania sądów kapturowych podczas bezkrólewia po nim oraz w trakcie interregnum po zgonie Stefana Batorego (12 grudnia 1576 r.), autor przedstawił ogólną charakterystykę litewskich zgromadzeń stanowych doby interregnum, które stanowiły forum podejmowania decyzji w tym trudnym czasie. Wspomniał o sejmikach odbywanych ,sposobem wojewódzkim", który to styl nie doprowadził jednak do wyparcia metody zwoływania zgromadzeń po powiatach, o sejmiku generalnym (głównym), a więcej uwagi poświęcił osobliwości litewskiego parlamentaryzmu w postaci tzw. konwokacji wileńskiej. Charakteryzując stan sądownictwa po ucieczce Walezego podkreślił natomiast znaczenie wydanego przez stany litewskie na jesiennym zjeździe 1574 r. w Wilnie „Porządku sprawiedliwości świętej”. Dokument wyznaczał tymczasowe ramy funkcjonowania działalności zwyczajnych sądów orzekających w imieniu króla i stał się rzeczywiście podstawą przywracania aktywności jurysdykcji w powiatach. Nie obyło się oczywiście bez pewnych oboczności organizacyjnych, a więc np. tworzenia lokalnych kapturów, a stąd także nowych komplikacji, które autor skrupulatnie wyjaśnia. Podobnie dla bezkrólewia po śmierci Batorego istotne znaczenie miało przyjęte 29 stycznia 1587 r. na zjeździe w Wilnie „Postanowienie i porządek około pokoju i sprawiedliwości i obrony ziemskiej” nazywane także „Kapturem Wielkiego Księstwa Litewskiego”, które miało obowiązywać do koronacji nowego monarchy. Ten ogólnie bardzo pozytywnie odebrany przez litewską szlachtę akt, którego postanowienia realizowano, był później przy podobnych okazjach wielokrotnie przywoływany w uchwałach sejmików oraz konwokacji wileńskich. Jego integralną, najobszerniejszą częścią był „Nowy porządek czynienia sprawiedliwości”, który przesądzał m.in. o dalszym procedowaniu spraw rozpoczętych przed zgonem króla oraz egzekwowaniu wyroków w sprawach już zakończonych. I tym razem nie obyło się bez wyjątków. Otóż uchwalony jeszcze w końcu grudnia 1586 r. przez szlachtę brzeską kaptur różnił się w niejednej kwestii od postanowień „Nowego porządku”, ale mimo to miał mocą „Kaptura Wielkiego Księstwa Litewskiego” utrzymać się w województwie brzeskolitewskim, którego terytorium i później będzie w tej dziedzinie z woli tamtejszej szlachty przestrzenią wielu odmienności. Ciekawym przypadkiem wskazanym przez autora było województwo mińskie, gdzie wyraźna wola szlachty odnośnie do powołania sądu kapturowego zderzyła się z obstrukcją ze strony starosty powodowanego inte- 
resami prywatnymi. W podsumowaniu rozdziału I O. Kanecki zaakcentował, że choć sądy kapturowe powoływane uchwałami sejmików pojawiły się na Litwie już po zgonie Zygmunta Augusta, to ,jednak pierwszym regulującym tę kwestię aktem o ogólnopaństwowym zasięgu” był wspomniany „Porządek sprawiedliwości świętej”. Traktowany jak „Kaptur Wielkiego Księstwa Litewskiego” nie uzyskał jednak takiego miana; otrzymała je nieco później uchwała z 29 stycznia 1587 r. Powszechna akceptacja tej ostatniej, znajdująca odzwierciedlenie w działalności sądów w zgodzie z jej postanowieniami, świadczyła natomiast zdaniem autora nie tylko o przyjęciu zasady o ustaniu sądów wraz ze śmiercią króla, ale także o „kształtowaniu się modelu organizacji państwa w bezkrólewiu", który był w stadium znaczącego zaawansowania już po śmierci Batorego (s. 84).

W rozdziale II zatytułowanym „Ustrój sądów kapturowych” (s. 85-135) najwięcej miejsca zostało poświęcone skomplikowanemu (choćby ze względu na mnogość form zjazdów szlacheckich w dobie bezkrólewia) procesowi ustanawiania jurysdykcji przedstawionemu przez autora całościowo $\mathrm{w}$ świetle wydarzeń kolejnych bezkrólewi, z równoczesnym omówieniem poszczególnych jego etapów. Mechanizm uruchamiał oczywiście uniwersał prymasa. W latach 1632 i 1648 jeszcze przed zwołanymi przez interrexa sejmikami odbyto zjazdy w Wilnie, gdzie potwierdzono moc postanowień „Kaptura” ze stycznia 1587 r., czyniąc jednak pole do ewentualnych korekt. Kolejnym etapem były obrady sejmików. Na podstawie laudów, instrukcji dla posłujących na sejmy konwokacyjne, autor starannie omówił, często różniące się w mnogich detalach, stanowiska poszczególnych lokalnych zgromadzeń szlacheckich w kwestii organizacji wymiaru sprawiedliwości w czasie kolejnych bezkrólewi. Dostrzegł właściwą laudom nawet drugiej połowy XVII w. tendencję do powielania wcześniejszych rozwiązań, co tłumaczył intencją szlachty polegania na sprawdzonych wzorcach, ale i zapobieżenia niepożądanym ingerencjom ze strony sejmu konwokacyjnego, zwłaszcza motywowanym politycznie. Zwrócił uwagę na obserwowaną i w XVII, i w XVIII w., a realizowaną różnymi sposobami, praktykę podawania do powszechnej wiadomości faktu ustanowienia sądu kapturowego w powiecie i wyboru jego sędziów. Sporo miejsca poświęcił kwestii stosunku kolejnych sejmów konwokacyjnych i przyjmowanych przez nie aktów konfederacji generalnej do lokalnych uchwał kapturowych. Zauważył, że reguła ustalania składu sądów kapturowych przez sejmiki przedkonwokacyjne znajdowała wyjątki w praktyce powoływania sędziów tej jurysdykcji przez sejmiki relacyjne odbywane po sejmie konwokacyjnym. Sporo uwagi poświęcił zaburzeniom, jakie przyniosło bezkrólewie z pierwszego dziesięciolecia XVIII w. oraz, wbrew próbom powrotu do wcześniejszych praktyk, również interregnum po śmierci Augusta II, a także wstrząsom, którym z powodów zaciekłej walki politycznej i rozdwojenia sejmików podlegał wybór sądów kapturowych w 1764 r. Rozdział II kończą zwięzłe, wyodrębnione w osobnych punktach rozważania poświęcone lokalnym konfederacjom jako związkom stanowiącym konieczną podstawę legalnego fundowania nadzwyczajnych jurysdykcji i wyboru sędziów, dalej typowym siedzibom sądów kapturowych, które mieściły się zazwyczaj na zamkach, w dworach hospodarskich, w izbach zwyczajnych jurysdykcji, czasami w ratuszach, a wreszcie wskazywanym w laudach podstawom prawnym orzecznictwa sądów kapturowych. Uchwały sejmików kazały sądzić według prawa pospolitego lub „porządkiem statutowym", według konstytucji sejmowych, ale także norm ustanowionych przez konfederacje, choć przewidywały też wyjątki od stosowania tych pierwszych źródeł. 
O. Kanecki klasyfikuje te wyjątki jako „istotne” (wprowadzenie jednoinstancyjności postępowania), zaraz dalej mówi o ,pewnych wyjątkach” itp. Budzącego dużą ciekawość wątku autor w tym miejscu nie rozwija, a nawet przyprawia czytelnika o pewne uczucie niepewności co do zakresu korekt wprowadzanych w dotychczasowym porządku przez lauda, gdy zostawia go ze stwierdzeniem narzucającym refleksję nad proporcjami: „Na podstawie norm konfederacji funkcjonować miał też kaptur nowogródzki po śmierci Jana III Sobieskiego, choć w części czynności sędziowie powinni kierować się prawem statutowym" (s. 134-135).

W najszczuplejszym objętościowo rozdziale III noszącym tytuł „Sąd kapturowy generalny" (s. 137-155) autor przedstawił genezę tytułowego, wspólnego Koroniarzom i Litwinom (co nie przeszło bez kontrowersji) sądu, który zaczęto ustanawiać na czas elekcji, począwszy od 1632 r.; dalej jego skład (tu m.in. problem postulowanego niełączenia funkcji sędziego w kapturze lokalnym i generalnym, sporów wokół zaprzysięgania marszałków wchodzących w skład sądu kapturowego generalnego, czasu wyłaniania sędziów) oraz siedzibę. Całość wieńczy zarys procesu przed omawianym sądem.

Nieporównanie obszerniej O. Kanecki zajął się procesem przed lokalnymi sądami kapturowymi. Autor rozbił to ogromne zagadnienie na dwa rozdziały swej pracy: rozdział IV („Proces przed sądami kapturowymi - zagadnienia ogólne”, s. 157-238) otwierają rozważania na temat ich zróżnicowanego składu, który był rezultatem odmienności wynikających z uchwał zjazdów szlacheckich oraz laudów. W ich świetle autor pracowicie ukazał dziesiątki zastosowanych w praktyce rozwiązań i mutacji. Zwrócił uwagę na wyraźną od schyłku XVII w., zresztą zbieżną z tym, co działo się w Koronie, tendencję do poszerzania składu kapturów aż do przesadnych rozmiarów stu i więcej sędziów w województwie, którą starał się okiełznać dopiero sejm konwokacyjny 1764 r. Następnie autor pochylił się nad niejednolitym sposobem wyboru marszałka sądu kapturowego oraz jego funkcjami, nad obowiązkami pisarza prowadzącego kancelarię oraz zatrudnionymi w niej regentami. Kilka uwag poświęcił instygatorom, nieco więcej woźnym. Przedstawiwszy w ten sposób uczestników postępowania, zajął się dalej problemami ewentualnego wyłączenia sędziego, zaprzysięgania sędziów i bezpieczeństwa sądów kapturowych. Obszernie omówił fundamentalne kwestie związane z właściwością sądów kapturowych, a więc kolejno: podmiotową (tę konstruowano szeroko, obejmując nią mieszkańców miast, duchowieństwo, przedstawicieli szlacheckiej służby gospodarskiej, a nawet chłopów, żołnierzy, dezerterów, Żydów i Karaitów); rzeczową (owszem z gruntu obliczoną na zapewnienie przede wszystkim bezpieczeństwa wewnętrznego, a więc związaną z kryminałami, ale nie tylko, skoro obejmowała np. sprawy o wykup dóbr zastawionych czy skarbowe i podatkowe, a i tak sejmiki dorzucały do tego zakresu laudami inne kwestie; w skrajność poszła w 1733 r. szlachta mścisławska, która utworzonemu przez siebie sądowi kapturowemu zagwarantowała prawo do sądzenia spraw kryminalnych i wszystkich spraw cywilnych, a uchwałę tę zaaprobował sejm konwokacyjny; kaptury miały zresztą tendencję do wykraczania poza przyznany ich kognicji zakres spraw); temporalną (rozciągającą się z mocy aktów kolejnych konfederacji generalnych zasadniczo od dnia śmierci czy abdykacji króla do dnia koronacji nowego monarchy, co zresztą odpowiadało oczekiwaniom sejmików; te same akta przewidywały też zawieszanie funkcji sądów kapturowych na czas sejmu elekcyjnego, co zmuszało znów do ustanowienia jurysdykcji zastępczych, które mogłyby powściągnąc swawolę; sądow- 
nictwo kapturowe zawieszano też w związku z powołaniem pospolitego ruszenia; autor wskazał i tu na tendencję do wykraczania poza określone przepisami ramy czasowe); miejscową (wyznaczoną przez klasyczne zasady). Rozdział IV kończą krótkie uwagi na temat stosunku sądów kapturowych do sądów kopnych.

Ostatni, V rozdział opracowania (s. 239-294) nosi tytuł „Przebieg procesu przed sądami kapturowymi”. Warto mu się przyjrzeć uważniej. Ujęta w tej części pracy materia została zaprezentowana według schematu: sesje sądowe, środki przymusu procesowego, inicjowanie procesu, pozwy i wynagrodzenia sędziów, regestry, dylacje, postępowanie dowodowe, zastępcy procesowi, rozprawa, ugody, wyroki, środki prawne przeciwko wyrokowi, postępowanie egzekucyjne. Problemy te zamknięto w osobnych punktach (podrozdziałach). Autor zaobserwował prawidłowość, że sesje sądów kapturowych rozpoczynano zazwyczaj pierwszego dnia kolejnych miesięcy. Czas ich trwania był zróżnicowany i wynosił od kilku dni do nawet miesiąca. Uchwały sejmików nie wyznaczały godzin pracy w ciągu dnia. O terminach posiedzeń, rodzaju spraw będących ich przedmiotem, limitowaniu obrad i innych kwestiach sądy kapturowe zwykły zawiadamiać uniwersałami. Dojście do skutku roczków było uzależnione od spełnienia wymaganego kworum. Autor przedstawił kilka mechanizmów przewidzianych przez lauda, które zabezpieczały przed jego brakiem (np. wybór osiadłego współpowietnika przez sędziów kapturowych czy zastępstwo pisarza ziemskiego przez odpowiedniego urzędnika grodzkiego). Wśród środków służących zapobieganiu uchylania się od odpowiedzialności O. Kanecki zwrócił uwagę na założenie aresztu, porękę i zakład. W ramach problematyki związanej z inicjowaniem procesu skupił się na odstępstwach od fundamentalnej zasady skargowości, które ukazał na przykładzie wytaczania powództw przez instygatorów czy poborców podatkowych. Nieco więcej napisał na temat pozwów i wynagradzania sędziów. Wskazał, że od woli sejmików zależało, czy membrany na pozwy wydawały kancelarie ziemskie, czy też grodzkie (ewentualnie z zasady obie), jaki był tytuł tych dokumentów, a także jak powinien brzmieć tytuł pozwów. Stwierdził, że uchwały nakazywały najczęściej, aby doręczenie pozwu następowało co najmniej dwa tygodnie przed rozpoczęciem sesji, choć reguła ta zawierała wyjątki i niektóre lauda wprowadzały termin tygodniowy. O. Kanecki zatrzymał się przez chwilę na sposobach doręczenia pozwów i wyraził przypuszczenie, że w praktyce najczęściej zostawiano je we wrotach dworu. Spostrzeżenia na temat wynagrodzenia sędziów zdają się natomiast wskazywać, że często lauda, posługując się ogólną formułą, nakazywały stosowanie prawa pospolitego lub też odwoływały się wprost do ustawodawstwa o Trybunale Litewskim, wskazując nawet czasem ostatnie jego nowelizacje. Rozwiązania te musiały być powielane przez poszczególne sejmiki podczas kolejnych bezkrólewi, w uchwałach bowiem pojawia się nierzadko lakoniczna dyspozycja odsyłająca do dawnych kapturów. Garść uwag poświęcił autor wniesieniu aktoratu oraz praktykowanej w poszczególnych sądach liczbie „wołań” sprawy. Odnosząc się do regestrów sądów kapturowych, podał przykładowe kategorie wpisów oraz krótko skomentował zjawisko mazania pozwów. Co się tyczy dylacji, stwierdził przede wszystkim wyraźne obostrzenia w zakresie ich stosowania w okresach bezkrólewi. Część laudów z gruntu i całkowicie wykluczało możliwość ich przyznania, a wiele dopuszczało je jedynie wyjątkowo, wyłącznie ze względu na obłożną chorobę pozwanego, choć jednocześnie relacje pamiętnikarskie zdają się sugerować, że w przyznawaniu dylacji sądy wcale nie były tak bardzo rygorystyczne i przyznawano 
je wielokrotnie. Przywołane przez autora wnioski o dylacje zdają się wskazywać, że najczęściej proszono o nie z racji choroby, kolizji spraw przed różnymi sądami, sprawowania funkcji poselskiej oraz służby wojskowej. Charakterystykę postępowania dowodowego rozpoczął autor od uwag na temat skrutynium prowadzonego najczęściej przez dwóch sędziów sądów kapturowych. Krótko odniósł się następnie do stosowania tortur, dowodów z treści dokumentów, do znaczenia relacji woźnych, do zeznań świadków oraz przysiąg. Wywody na temat zastępców procesowych w małym stopniu, jak się wydaje, oddają specyfikę sądów kapturowych. Niknie ona wśród uwag terminologicznych, ogólnych wiadomości o specyfice staropolskiej palestry i jej breweriach oraz dość powierzchownej analizie przepisów statutowych. Następnie autor krótko prześledził przebieg rozprawy; kilkoma uwagami skwitował możliwość zawarcia ugody; by przejść do omówienia wyroków. Zastanawiał się przez chwilę nad czytelnym w świetle akt sądów kapturowych procesem zastępowania języka ruskiego przez polski w drugiej połowie XVII w. oraz nad stroną formalną wyroków. W kontekście przytoczonych przykładów, a więc przede wszystkim aktu konfederacji generalnej z 1587 r., późniejszych postanowień sejmów doby kolejnych bezkrólewi, ale przede wszystkim licznych uchwał sejmików litewskich jasno klaruje się podstawowa zasada, że wyroki sądów kapturowych miały walor orzeczeń ostatecznych. Inna rzecz, że siedemnastowieczne i osiemnastowieczne akty konfederacji generalnych, określając właściwość rzeczową sądów kapturowych, przewidywały możliwość uchylania ich dekretów wydanych z jej naruszeniem. Czyniły to niejednokrotnie sejmy koronacyjne (także ze względu na naruszenie właściwości temporalnej). Czasami w obawie przed skutkami egzekucji po zapadłym wyroku strony, nie czekając na sejm, próbowały uciekać się do improwizowanych rozwiązań. W przypadku zaś pogwałcenia procedury strony usiłowały odwoływać się do sejmu elekcyjnego. W ostatnim punkcie rozdziału zostało omówione postępowanie egzekucyjne. W aspekcie laudów autor wskazywał na różnorodne rozwiązania przyjmowane przez sejmiki co do poszczególnych elementów tej procedury, a więc: terminów wykonania, osób dokonujących egzekucji (np. sędzia kapturowy; woźny wraz z dwoma szlachcicami), sposobów złamania ewentualnego oporu.

Trzeba przyznać, że O. Kanecki podjął się zadania nadzwyczaj ambitnego, ponieważ z samej natury rzeczy problematyka procesu litewskiego jest niebywale trudna i skomplikowana. Nie ułatwia też zapewne sprawy z gruntu obszerny, a i z tendencją do poszerzania, zakres właściwości kapturów, jak również przyjęcie w pracy szerokich, bo obejmujących ponad dwa wieki, ram chronologicznych. Starał się więc autor w dwóch rozdziałach stanowiących łącznie połowę całkowitej objętości opracowania przedstawić proces przed sądami kapturowymi, poświęciwszy, jak widzieliśmy, rozdział IV zagadnieniom ogólnym, a V przebiegowi postępowania. W tym ostatnim odtwarzał więc kolejne fazy procesu na podstawie tego, co zobaczył w treści aktów konfederacji generalnych, laudów i instrukcji sejmikowych, uchwał sejmów elekcyjnych i koronacyjnych oraz tego, co odkrył w aktach procesowych - i pewien obraz rzeczy, choć bardzo uproszczony w stosunku do tego, co wiemy o meandrach tej skomplikowanej procedury, udało mu się oddać. Szukał ponadto, jak już zostało wspomniane, wszelkich elementów, które postępowanie przed kapturami (a miało się ono toczyć, jak kazały uchwały sejmików, według prawa pospolitego, prawa statutowego) odróżniały od procesu w czasie regnum. Otóż wydaje się, że w tym ważnym punkcie autor chybił celu, tego bowiem, co 
odczytywał we wspomnianych źródłach, nie zestawiał z przepisami statutowymi i konstytucjami sejmowymi, a w konsekwencji poszukiwane różnice nie miały szansy wyraźniej wybrzmieć. Przede wszystkim bardzo dziwi fakt, że autor w ogóle w sposób nader oszczędny sięga do litewskiej kodyfikacji. Czasem mówi o przepisach statutowych najogólniej bez żadnych odniesień do konkretnych artykułów. Stwierdza na przykład, że schwytani na gorącym uczynku przestępcy powinni zostać osądzeni bez pozwu i że „Było to zgodne z regulacjami Statutu litewskiego” (s. 83, przyp. 276) albo, że (pomijam, że to nie najszczęśliwsze sformułowanie) „Znaną III Statutowi litewskiemu praktyką było też zapisywanie w aktach sądowych zeznania woźnego o doręczeniu pozwu" (s. 256). W ostatniej części pracy, która traktuje o przebiegu procesu, przywołał ich zaledwie kilkanaście, głównie z najobszerniejszego, liczącego 105 artykułów, rozdziału IV („O sędziach i o sądziech”). Nie wiadomo też, dlaczego autor prawie zupełnie pominął konstytucje sejmowe, których przepisy miały przecież, nie tylko dla kształtu procedury, istotne znaczenie, czego zawsze dowodzi obraz wyłaniający się z kart akt procesowych, na których przywoływane nader często ustawy splatają się w charakterystyczny sposób ze statutowymi artykułami, tworząc nierozłączną całość ${ }^{2}$. Ten zupełnie oczywisty, naturalny i mocny, wyrobiony przez wieki współistnienia, związek znalazł odbicie w tytule dzieła Michaiła Nowakowskiego ${ }^{3}$, którego, nawiasem mówiąc, O. Kanecki nie wykorzystał. Tymczasem jeśli autor w ogóle sięga do ustawodawstwa sejmowego, to jest to prawie bez reszty ustawodawstwo sejmów doby bezkrólewia. Wypada też dla porządku wspomnieć, że w związku z przyjętym zakresem terytorialnym trzeba byłoby także mieć na uwadze i liczyć się z lokalnymi odrębnościami wynikającymi z miejscowych zwyczajów, choć z pewnością sztuka ich identyfikacji i rozróżniania w niuansach należy do zadań najtrudniejszych.

Nawiązując do wspomnianych luk w zakresie wykorzystania Statutu chciałbym, choć będzie to w pewnej mierze powtórką, zwrócić uwagę na kilka przykładowych wątków pracy, w których ten brak jest jaskrawo widoczny. Jak zostało wspomniane, O. Kanecki zaobserwował rozpowszechnioną praktykę rozpoczynania posiedzeń sądów kapturowych (np. kaptur słonimski, żmudzki, grodzieński) pierwszego dnia kolejnych miesięcy (s. 242), ale nie nadmienił, że odpowiada to dokładnie statutowemu stylowi odbywania roczków sądów grodzkich (IV, 33). Poruszył kwestię komplikacji wynikających z braku kworum na skutek absencji urzędnika (lub niezłożenia przez niego przysięgi) i na tym tle zwrócił uwagę na wprowadzenie przez szlachtę zgromadzoną w 1632 r. w Wołkowysku pewnego rodzaju mechanizmu awaryjnego w postaci możliwości wyboru przez obecnych sędziów sądu kapturowego innego szlachcica osiadłego w powiecie jako zastępcy nieobecnego (s. 246), ale przemilczał, że Statut znał dość rozbudowaną, rzec można wielopiętrową, procedurę uzupełniania składu sądu ziemskiego (IV, 4), a więc pewne gotowe wzorce były pod ręką. Pisze autor o membranach służących do sporządzania pozwów (s. 251 i n.), ale nie odsyła czytelnika do żadnych przepisów statutowych (np. do IV, 6; IV, 18; IV, 34). Wzmiankuje dalej o uchwale szlachty trockiej z 1696 r. w sprawie praktyki zbijania pozwów (s. 253) i przytacza drobny urywek laudum, ale przecież i ten ułomek wystarczy, aby zastanowić się nad tym, czy nie wprowadzono tam czasem "

\footnotetext{
2 Zob. Zakrzewski, Statut, 203-13.

3 Nowakowski, Oczerk sudoustrojstwa.
} 
graniczenia w stosunku do tego, co postanowiono w Statucie (IV, 19). Wydaje się, że odpowiedź powinna być twierdząca. Tymczasem autor tego detalu zupełnie nie dostrzega. Mówi dalej o doręczaniu pozwów (s. 253 i n.), a więc o terminach, o sposobach (,oczywisto”, „na imieniu”), o „opowiadaniu i obwołaniu” dokonywanym przez woźnego, ale milczy o tym, że Statut reguluje to dokładnie w obszernym artykule (IV, 17). Do wyjątków należy więc sytuacja, kiedy czyni spostrzeżenie takie jak to pozostające w związku z uchwałą sejmiku brzeskiego z 1648 r. (s. 258), która polecała pisarzowi sądu kapturowego przybycie do siedziby sądu w przeddzień rozpoczęcia roków w celu wpisywania spraw do regestru, a mianowicie że odbiega ona od tego, co stanowi Statut w artykule 16 z rozdziału IV (zgodnie z którym skład sądu ziemskiego był zobligowany do przybycia do siedziby sądu na trzy dni przed rokami „dla otworzenia ksiąg i wydawania wypisów, komu tego potrzeba będzie, także dla wpisowania pozwów w rejestr, aby ten, kto się do rejestru pierwej wpisze, też naprzód sądzon był"). Tego ostatniego passusu nie kojarzy jednak z kolejnością rozpatrywania spraw, o której wzmiankuje na tej samej stronie. Zaraz dalej (s. 259) autor wylicza liczne przykłady pozywania na rok zawity przed sądy kapturowe, ale nie odnosi się wcale do obszernych przepisów statutowych (art. 22, 23, 24, 42 z rozdziału IV). Zwłaszcza rzeczony art. 42 wymienia 25 kategorii spraw i kwalifikuje je na roki zawite, a nie jest to przecież katalog zamknięty. Czy wreszcie w kontekście wyjątku:

A w tych wszystkich rzeczach, tym rokom zawitym podanych $w$ tym artykule, $i$ też w inszych artykułach tego Statutu opisanych, za pozwy ziemski rok ma trwać wedle dawnego obyczaju prawa do trzeciego dnia, tak pozwanej jako powodowej stronie. A gdzie by która strona przez trzy dni za wołaniem woźnego bez przyczyn prawnych w Statucie tym zamierzonych nie stała, tedy już w tej rzeczy na pozwie opisanej upada i wiecznie traci (IV, 42),

nie należałoby przemyśleć raz jeszcze tego, co w istocie przewidywało laudum brzeskie z 1648 r. mówiące o jednym wołaniu zamiast trzech? Autor zwraca zresztą uwagę na różnice w liczbie wołań ordynowanych przez poszczególne lauda - mówi o jednym, trzech, a nawet czterech, co miało być przejawem odstępstwa od, jak mówi, ,prawnego wymagania", ale nie wspomina o jego podstawie (s. 259). Mówi o tym jednak Statut w art. 16 rozdziału IV. Wydaje się, że owo oderwanie narracji od przepisów litewskiej kodyfikacji widać wyraźnie w wywodach autora na temat poszczególnych czynności i decyzji sądów odzwierciedlonych w regestrach (s. 260 i n.). Wymienia je jednym tchem, powołując się na regestry, ale ich podstawy prawne pozostawia na stronie. Podobnie czytelnik zderza się z pewną niewiadomą, gdy autor, mówiąc o dylacjach i niebezpieczeństwie przewlekania postępowania w związku z ich stosowaniem, stwierdza, że uchwały sejmików doby bezkrólewi obostrzały ich stosowanie (s. 262). Obostrzały w stosunku do czego? Wskazuje na obmowy związane z pełnieniem funkcji poselskiej (s. 264) i wiąże je słusznie z art. 47 z rozdziałem IV i art. 22 z rozdziałem I, ale nie czyni już tego w przypadku ewidentnego wniosku o dylację podpieranego sprawą o większe, o czym Statut stanowi w art. 27 w rozdziale IV. W kontekście środków dowodowych autor wymienił tylko art. $77 \mathrm{z}$ rozdziału IV, ale nie wiadomo, dlaczego nie przywołał szeregu innych (art. 76, 78, 79, 81, 82). Pisze też o laudum lidzkim z 1648 r., które nakazywało sporządzenie wyroku na piśmie, ,ponieważ w takiej formie był następnie odczytywany”. A cóż innego postanawiał Statut (IV, 3)? Wydaje się, że trzeba by tu ra- 
czej pochylić się nad innym elementem uchwały, w którym polecała ona wyrokującym sędziom ,głosowanie w obecności stron” i w tym kontekście ocenić rzekome ,incydenty sprzed izby sądowej” (s. 279).

Podobnych przykładów można by podać dużo więcej, ale zwrócę uwagę na inne jeszcze zagadnienie. Otóż praca nie zaspokaja ciekawości czytelnika co do liczby oraz charakteru spraw, z którymi najczęściej miały do czynienia sądy kapturowe w Wielkim Księstwie Litewskim. Czytelnik otrzymuje w tej mierze tylko pośrednie wiadomości, które wynikają najczęściej raczej z pewnych kontekstów niż z bezpośrednich wyjaśnień autora. Jest to dziwne wobec faktu, że został zgromadzony duży materiał źródłowy. Tymczasem rzecz jest i ważna, i bardzo ciekawa. Czytelnik rad by się dowiedział, co przeważało w okresie grozy, za jaki szlachta uważała bezkrólewie? Czy rzeczywiście dominowały sprawy karne, czy może, jak już zresztą wykazywano w cząstkowych badaniach, nie brały one wcale góry wśród ogółu rozpatrywanych spraw. Jakie zatem były przybliżone proporcje spraw poszczególnych kategorii (kryminalnych, cywilnych) i w jakim stosunku pozostają one do tych z okresu regnum? Wreszcie, czy da się zaobserwować np. tendencje do zaostrzanie sankcji, jakieś ślady wzmożonej surowości sądów? Te pytania pozostają bez zadowalającej odpowiedzi.

Wskażę jeszcze na pewne potknięcia i usterki innego pokroju. Nie do końca rozumiem, cóż nadzwyczajnego kryje się w konstatacji, którą autor powtarza za Zinaidą Antanowicz, że wśród powodów stających przed grodzieńskim sądem kapturowym w końcu lat sześćdziesiątych XVII w. przeważali mężczyźni; chyba trzeba by o tym powiedzieć, gdyby było odwrotnie. Snując refleksję nad znaczeniem niektórych terminów lub nad instytucjami prawnymi, autor odwołuje się czasem za pośrednictwem literatury do prawa i praktyki koronnej, czasem mazowieckiej czy tej obserwowanej w Prusach Królewskich (np. na s. 258, 261), co oczywiście może mieć pewien walor porównawczy. Brakuje jednak wtedy wyraźnego wskazania, jak rzecz wyglądała w analizowanym prawie litewskim, czytelnik zostaje wobec tych zestawień z krztyną niepewności. Do objaśniania terminów (oczywiście nie tylko tych związanych z prawem procesowym) O. Kanecki wykorzystywał encyklopedie staropolskie Zygmunta Glogera, Aleksandra Brücknera, słownik staropolszczyzny (Słownik języka polskiego XVII i 1. połowy XVIII wieku); lepiej, że przywoływał na pomoc Tomasza Umiastowskiego, Aleksandra Korowickiego (na tym tle dość sztucznie wygląda posiłkowanie się pracą Stanisława Janczewskiego o adwokaturze dla wyjaśnienia terminu ,regestr”, s. 260) oraz Juliusza Makarewicza i Oswalda Balzera, ale nie wiadomo, dlaczego nie sięgnął w tym celu do popularnego i docenianego nawet na początku XIX w. opracowania pod tytułem Prawa ze Statutu Wielkiego Księstwa Litewskiego i Konstytucji dla wygody pilnujacych z urzędu albo potrzeby sadów $i$ dla inszych obywatelów koronnych i litewskich wiadomości porzadnie podtug alfabetu zebrane (Warszawa 1783). Może przydałaby się tu także pomocniczo praca Franca Borgiasza Piekarskiego, Zbiór praw polskich i W. X. Litewskiego od r. 1347 sejmu wiślickiego, aż do r. 1786 podtug sławnych Heyneccyusza i Höpfnera prawników, porządkiem ułożony (Kraków 1813).

Co się tyczy spożytkowanej literatury, to dziwi nieco brak pracy Iwana I. Łappo 4 . Do bezkrólewia po śmierci Jana III Sobieskiego i interregnum z pierwszej połowy

\footnotetext{
${ }^{4}$ Łappo, 1588 metu Lietuvos Statutas.
} 
XVIII w. oraz licznych kwestii szczegółowych przydałaby się praca Jacka BurdowiczaNowickiego ${ }^{5}$. Szereg rzeczy można by dorzucić do wątków dotyczących opieki nad małoletnimi, adwokatury, interrexa, zjadania pozwów, Tatarów i in.

Książka O. Kaneckiego otrzymała atrakcyjną szatę graficzną. Solidna i dobrze zaprojektowana okładka, oryginalne wyklejki, ilustracje będące w części reprodukcjami dzieł sztuki, w części zdobnych kart rękopisów, rycin ze starodruków czy dokumentów praktyki są ciekawe i robią korzystne wrażenie.

Co się tyczy kwestii natury technicznej, wydaje się, że zastosowanie kryterium chronologicznego w odniesieniu do kolejności pozycji cytowanych w przypisach wpłynęłoby korzystnie na ich klarowność. Nie może być to pewnie zarzutem, ale zastosowany w pracy styl cytowania czasopism jest w swym nadmiarze dość osobliwy. Staranność autora i korekty sprawiły, że w pracy znajdują się tylko bardzo nieliczne usterki techniczne (do istotniejszych należą: na s. 22 w zdaniu: „Poza zakresem prowadzonych badań znalazł natomiast powiat piltyński” wypadło „się”; na s. 38 jest: ,z jednaj strony”; na s. 190 błędnie zapisano „nie dopuszczono”). Drobniutkie potknięcia techniczne tkwią: na s. 250 (przyp. 79), s. 265 (przyp. 207).

Podsumowując, należy stwierdzić, że O. Kanecki zmierzył się z problemem doniosłym i bardzo wymagającym. Jego praca, oparta na pokaźnym i różnorodnym materiale, zwłaszcza pracowicie wydobytych, obszernych i cennych archiwaliach, odznacza się licznymi walorami i warta jest uwagi. Wydaje się, że książka jest lepsza w części dotyczącej genezy i ustroju sądów kapturowych, słabsza w partiach opisujących przebieg procesu, ale zasadniczo niewątpliwie zasługuje na wysoką ocenę. Można przypuszczać, że monografia stanie wśród tych opracowań, które w znaczący sposób przyczyniły się do poszerzenia zakresu wiedzy na temat sądów kapturowych w Wielkim Księstwie Litewskim.

\section{Bibliografia}

Abramski, Andrzej, Huras, Andrzej. Sądy kapturowe (1572-1764). Studium z dziejów sądownictwa i prawa sądowego podczas bezkrólewi w Rzeczypospolitej szlacheckiej. Sosnowiec: Wydawnictwo Wyższej Szkoły Inżynierii Bezpieczeństwa i Ekologii, 2010.

Burdowicz-Nowicki, Jacek. Piotr I, August II i Rzeczpospolita 1697-1706. Kraków: Arcana, 2013.

Łappo, Iwan I. 1588 metu Lietuvos Statutas, t. I, cz. 1 i 2. Kaunas: Spindulio, 1934-1936.

Nowakowski, Michaił M. Oczerk sudoustrojstwa i grażdanskago procesa po bywszemu statutu i konstitucijam. Peterburg: izdanie Gosudarstvennoj kancelarii, 1863.

Piekarski, Franc B. Zbiór praw polskich i W. X. Litewskiego od r. 1347 sejmu wiślickiego, aż do r. 1786 podług sławnych Heyneccyusza i Höpfnera prawników, porzadkiem ułożony. Kraków: Drukarnia Akademicka, 1813.

Prawa ze Statutu Wielkiego Księstwa Litewskiego i Konstytucji dla wygody pilnujacych z urzędu albo potrzeby sądów i dla inszych obywatelów koronnych i litewskich wiadomości porzadnie podtug alfabetu zebrane. Warszawa: Michał Gröll, 1783.

\footnotetext{
${ }^{5}$ Burdowicz-Nowicki, Piotr I, August II.
} 
Zakrzewski, Andrzej B. „Statut w konstytucjach, konstytucje w Statucie, XVI-XVIII w.” W: Lietuvos Statutas. Temides ir Klejos teritorijos. Straipsniu rinkinys, sud. Irena Valikonytė ir Neringa Šlimienė 203-13. Vilnius: Vilniaus universiteto leidykla, 2017. 